\title{
Examining the Self-Efficacy of Prospective Teachers in Technology Integration According to their Subject Areas: The Case of Turkey*
}

\author{
Omer Simsek \\ Dicle University, Turkey \\ ORCID: 0000-0001-8222-1920 \\ Taha Yazar \\ Dicle University, Turkey \\ ORCID: 0000-0002-2285-4889
}

\begin{abstract}
The purpose of this study is to examine prospective teachers' TPACK self-efficacy and variables affecting their training to integrate technology in education according to their subject areas. The survey research, a quantitative research method, was used in the study. The sample of the study is composed of senior prospective teachers $(n=3553)$ from 19 different departments of 18 state universities in Turkey. The departments were gathered into nine subject areas by taking into consideration the criteria of prospective teachers' subject areas. Mann-Whitney $\mathrm{U}$ and Kruskall-Wallis $\mathrm{H}$ tests were used for the comparisons of the groups. The results of the study show that TPACK is perceived differently according to the subject areas. Prospective teachers think that teacher educators do not sufficiently exhibit technology integration behaviors in their lessons and participants think that they somewhat have authentic experiences in using technology in education. While both scores of TPACK self-efficacy and variables affecting prospective teachers' training to integrate technology in education are higher in favor of Foreign Languages subject area; prospective teachers in Mathematics and Turkish language have lower scores than other subject areas in the study. As a result, the self-efficacy of prospective teachers' technology integration significantly differentiates.
\end{abstract}

Keywords: Technology integration; TPACK; Prospective teachers; Self-efficacy

\section{Introduction}

The more the role of technology increases in daily life, the more its varieties of usage increases in school environments. The possibilities of accessing technological infrastructure are improved in this context. However, equipping classes with hardware and software does not mean that these are used effectively (Zhao \& Frank, 2003). The people who make learning meaningful are the teachers who integrate these tools and resources with pedagogic methods (Ertmer, 2005; Goktas, Yildirim, \& Yildirim, 2009; Tondeur, van Braak, Siddiq, \& Scherer, 2016).

\footnotetext{
* This study was part of the first author's doctoral dissertation, which was completed under the supervision of the second author.
} 
On the other hand, it is a complicated process for teachers to meet this criterion (Mumtaz, 2000) and improper or insufficient use of technology in education can cause learning to get worse (Borko, Whitcomb, \& Liston, 2009). In this context, it is the responsibility of Faculties of Education to train prospective teachers to acquire technological, pedagogical and content knowledge (TPACK) (Tondeur, Scherer, Siddiq, \& Baran, 2017).

Technological Pedagogical Content Knowledge (TPACK), which stresses the integration of teachers' technological abilities into education, has revealed a new perspective on teachers' skills in recent years, and various studies have been conducted on this topic in international context (Jamieson-Proctor et al., 2012). While the number of studies based on TPACK providing guidance to educators and researchers about the effective integration of technology, including teacher training programs (Mishra \& Koehler, 2006) has gradually increased; the number of studies examining teachers' Information and Communication Technology (ICT) usage according to their subject areas are insufficient (Tay, Lim, \& Lim, 2015) and these kinds of technology integration frameworks are still in their first phase (Angeli \& Valanides, 2015; Cavanagh \& Koehler, 2013). Especially definition of these frameworks can be detailed by the studies focusing on different curriculum and different subject areas because the content knowledge of each subject area, the learning-teaching process, the quality of the material used and the processes of assessment and evaluation differ from each other. Therefore, the qualifications required for TPACK may not be perceived in the same way. Indeed, while Darby (2009) states that the integration of ICT in education is related to the culture of the subject area, including its structure and functioning, Karaseva Siibak and Pruulmann-Vengerfeldt (2015) explain that the use of digital technologies is related both to the subject area and to dominant pedagogical beliefs. For this reason, it has been stressed that studies should be conducted to show how TPACK differs according to subject areas (discipline, teaching field etc.) or how it is related to these (Voogt \& McKenney, 2017).

It is important that prospective teachers acquire effective technology integration qualifications before entering the teaching profession full-time. Besides the opinions of prospective teachers about technology usage (Tondeur, van Braak, Sang, Voogt, Fisser, \& Ottenbreit-Leftwich, 2012) and pedagogical beliefs (Bandura, 1986) in education have an important influence on their future experiences of technology. Prospective teachers' beliefs in their capabilities to organize and execute the TPACK can produce self-efficacy (Bandura, 1997) in technology integration. Moreover, Abbit (2011) states that prospective teachers' self-efficacy belief is correlated with the TPACK model. For this reason, curriculum should be examined so that prospective teachers can gain experience about technology in various ways while they are in training (Krueger, Hansen, \& Smaldino, 2003). It will be easier to formulate a plan to integrate technology in education by considering the TPACK self-efficacy of prospective teachers and their views on the variables about preparing them to integrate technology in their educational practice. The variables about preparing prospective teachers to integrate technology in this study are; (a) Capacity of using computers, (b) Capacity of using the internet, (c) Attitude towards using technology in education, (d) Access to technology resources, (e) Teacher educators as role models, (f) Authentic technology integration experiences, (g) Using ICT when developing educational materials, and (h) Collaborating with peers in using technology. Examining them separately may limit the development of teachers' ability to integrate technology during their training. However, comparing these variables, in particular according to subject areas, may provide an insight to structure relevant curriculum. Also prospective teachers' self-evaluations about themselves and their institutions will make a contribution to educational technology field in terms of preparation of an effective technology integration map in education. 


\section{Theoretical Framework}

\section{Disciplinary Differences in Integration of Technology in Education}

Technology integration in education is a research interest which is commonly studied and about which various methods have been put forward. According to Hsu (2010), teachers should be able to access multiple sets of information and benefit from content, technological and pedagogical information so that technology can be integrated into education. However technology integration in education may not be a norm or a significant part of the culture of some teaching areas, or it may not conform to certain disciplines. A discipline is a major factor in shaping the several aspects of course planning and teaching (Waggoner, 1994). Therefore, the structure and content of subject matter shapes the ways of technology integration (Yeh, Hsu, Wu, Hwang, \& Lin, 2014). For this reason, teachers may think differently about integrating their own subject areas with technology (Tay, Lim, \& Lim, 2015). For example, science and mathematics teachers found their topics to be more related to technology in the study of John and Baggot la Velle (2004), while history teachers stated that they use technology in a limited way because the topics studied are based on a humanist perspective. Again, while all Science and English language teachers believed that their subject was suitable for integration with ICT, Literature and Mathematics teachers did not, according to the study of Kula and Deryakulu (2017).

Zelkowski, Gleason, Cox, and Bismarck (2013) stated that mathematics' prospective teachers had difficulties in expressing Technological Content Knowledge (TCK), Technological Pedagogical Knowledge (TPK) and Pedagogical Content Knowledge (PCK). In Niess' (2005) study, which is about how science and mathematics prospective teachers prepared courses with technology, it is stated that the integration of technology accords with the nature of the teaching is an important element affecting the development of TPACK. Accordingly, it is possible to find studies stressing that the nature of mathematics makes it difficult to integrate ICT into the courses (Kula \& Deryakulu, 2017). Again Niess et al. (2009) assert that as TPACK standards, TPACK development methods and new technologies emerge and as the number of studies about teaching-learning increases, the usage of these technologies changes. Considering the explanations in the literature, it has been seen that technology integration in education is evaluated differently in various disciplines. Of course, the depth, intensity, culture or functioning of the curriculum of each subject area may vary from country to country. In this study, technology integration self-efficacy of a large sample of teachers in different disciplines in Turkey was examined. This study, conducted with a large sample, may contribute to the literature in making comparisons at both local and international levels.

\section{Technological Pedagogical Content Knowledge Model}

The TPACK model that Mishra and Koehler presented as a framework for technology integration in 2006 and which has been examined by many international and domestic researchers (i.e. Turkish) has offered a clear and beneficial structure for those researching about the integration of technology in learning and teaching (Baran, Chuang, \& Thompson, 2011) and has critically affected education technology studies and applications (Koehler, Shin, \& Mishra, 2012). This structure covers the three basic knowledge components of teachers. These are Content Knowledge, Pedagogical Knowledge and Technological Knowledge. Content 
Knowledge includes the subject area to be taught or learned, Pedagogical Knowledge includes applications, processes, strategies, activities and teaching-learning methods, and Technological Knowledge includes the overhead projector, black/whiteboards and the books which are commonly used, as well as modern technologies such as computers, the internet and video (Koehler \& Mishra, 2008). Technological Content Knowledge, Pedagogical Content Knowledge and Technological Pedagogical Knowledge emerged as the interaction of these principal three structures have emerged. TPACK is the joint interaction of these three fundamental bodies of knowledge (Koehler \& Mishra, 2008). Pedagogical content knowledge (PCK) requires the application of specific subject areas of teaching knowledge. TCK is an understanding of the manner in which technology and content influence and constrain each other. Teachers must figure out which technology is appropriate for the subject area and how to use it in education. TPK is an understanding of how teaching and learning can change when particular technologies are used in particular ways (Harris, Mishra \& Koehler, 2009). Voogt et al. (2012) acknowledged that this framework has resulted from technology integration with a specific educational content and that teachers should integrate content, pedagogy and technology carefully and should also be qualified in these three fields. The knowledge structure that emerged as TPACK can be seen as the 21st century skill required for the classes which adopt cooperative learning environments using ICT. According to the TPACK literature, there are different models which take this framework interdependently or separately. For instance, Angeli and Valanides (2009) address TPACK as a unique body of knowledge in the transformative model. Kabakci Yurdakul et al (2012) distinguished different competencies for TPACK as designing instruction, implementing instruction, ethical awareness and proficiency in the TPACK-deep model. Lee and Tsai (2010) bring forward TPACK-Web as another model while integrating Web technology into their pedagogical practice.

Numerous scales have been developed to measure TPACK self-efficacy of prospective teachers (Aydın-Gunbatar, Boz, \& Yerdelen-Damar, 2017; Chai, Koh, Tsai, \& Tan, 2011; Kabakci Yurdakul, Odabasi, Kilicer, Coklar, Birinci, \& Kurt, 2012). Prospective teachers' TPACK self-efficacy measurement tools are about their availability to integrate technology in education. Also these tools either measure TPACK self-efficacy for only one specific subject area group or various groups. In order to better prepare prospective teachers to integrate technology in education, these tools can help understand the pedagogical issues they encounter in their education period. In the current study, TPACK-ISTE self-efficacy belief is the TPACK self-efficacy based on ISTE standards for teachers (Simsek \& Yazar, 2016), and is considered as indicating prospective teachers' beliefs on the capacity to effectively use technology (Wang, Ertmer, \& Newby, 2004). TPACK-ISTE self-efficacy, which is closely related to teachers' beliefs concerning their capability to appreciate technology integration in education, plays a crucial role in knowing and implementing TPACK (Lai \& Lin, 2018).

\section{Preparing Prospective Teachers to Integrate Technology in Education}

In literature, there are many studies about the integration of technology in education structured within the framework of the models for teachers (Kopcha, 2010; Roblyer, 2006; Toledo, 2005; Wang, 2008). However, Tondeur et al. (2012) tried to establish a model of technology integration for a more specific group in terms of educating prospective teachers. Unlike the integration of technology developed at the level of the individual teacher or school, Tondeur et al. (2012) developed a model to prepare prospective teachers to use technology by synthesizing qualitative studies. This model, focusing on what strategies are important when 
prospective teachers use technology, presents key themes consisting of three parts which have been created by synthesizing qualitative studies about this topic in the literature. In this model, the researchers reviewed qualitative studies that focused on strategies to prepare preservice teachers to integrate technology into their lessons in order to identify effective strategies. That is why they call this model as SQD (Synthesize Qualitative Data) model. This model includes two principal themes (training teachers for technology integration in education and institutional context) that has emerged from this model based on qualitative studies in the literature (see Figure 1). Key themes related to the institutional level comprise of training staff, technology planning and leadership, cooperation between institutions and access to resources. These themes are important to define efficient technology integration process but prospective teachers may have limited or incorrect observation about them.

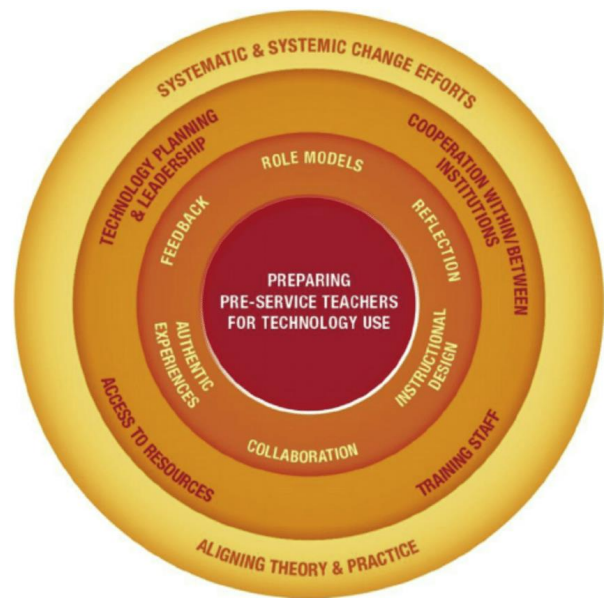

Figure 1. SQD Model to Prepare Pre-service Teachers for Technology use

Therefore, the second principal theme is focused in the study. The key themes related to the preparation of prospective teachers examined in this study are; views about teacher educators as role models, attitudes about the role of technology in education, learning technology by design, collaborating with peers, scaffolding authentic technology experiences and access to resources. These key themes are translated into Likert-type items as; capacity of using computers, capacity of using the internet, attitude towards using technology in education, access to technology resources, teacher educators as role models, authentic technology integration experiences, using ICT when developing educational materials, collaborating with peers in using technology. The variables in this model emphasize the need for prospective teachers to provide effective technology integration. In the framework of these opportunities and competencies, prospective teachers in different subject areas can develop ICT skills. However, it is not known exactly what these opportunities are for each teaching branch. It should also be determined whether these facilities and competences differ statistically. Taking into consideration both TPACK-ISTE self-efficacy and the variables in the SQD model could offer a new perspective specifically in preparing/educating prospective teachers for integrating technology in education.

Apart from TPACK self-efficacy, the key themes of the model are "variables in training prospective teachers to integrate technology in education" in this study. The variables about technology integration in education proposed in this model are investigated by comparing the scores of different subject areas of prospective teachers. And the variables do not directly resemble their behaviours; they resemble prospective teachers' views. 


\section{Purpose of the Study and Research Questions}

The main purpose of this study is to compare TPACK-ISTE self-efficacy scores of prospective teachers and the scores of variables affecting their training to integrate technology in education according to their subject areas. In addition the correlation of the numbers of significant differences in TPACK-ISTE self-efficacy and the numbers of significant differences in variables affecting prospective teachers' training to integrate technology in education is investigated. For this purpose, answers were sought to the following research questions.

1. Do the TPACK-ISTE self-efficacy scores of prospective teachers show statistically significant differences according to their subject areas?

2. Do the scores of variables about training prospective teachers to integrate technology in education show statistically significant differences according to their subject areas?

3. Is there a statistically significant relationship between the differences in TPACK-ISTE self-efficacy scores according to subject areas and the differences in variable scores about training prospective teachers to integrate technology in education?

\section{Method}

\section{Research Model}

The survey research, a quantitative research method, was used in the current study which aims to determine TPACK-ISTE self-efficacy and views of prospective teachers about the variables affecting their training to integrate technology in education. This model is a quantitative research type conducted in order to describe the tendencies, attitudes or opinions of individuals in a sample from a population selected with a data collection tool (Creswell, 2012).

\section{Population and Sample}

The population of study was composed of prospective teachers who were senior university students in Faculties of Education in state universities during the spring semester of the 20142015 academic year in Turkey and prospective teachers who were attending the pedagogical formation certification program. The sample of the study was composed of senior prospective teachers of 18 state universities selected randomly with the cluster sampling method in various geographical regions $(n=7)$ of Turkey. According to the sample calculations, the sample of this study ( $n=3553)$ represented the population ( $N=93725)$ according to the margin of error $(5 \%)$ and confidence interval (99\%) for the sample limit $(n=659)$. Gender and demographic information about subject areas of the participants in the study is presented in Table 1.

Table 1. Demographic Characteristics of Participants

\begin{tabular}{llcc}
\hline Variable & Property & $\mathrm{n}$ & $\%$ \\
\hline \multirow{3}{*}{ Gender } & Male & 1328 & 37.6 \\
& Female & 2202 & 62.4 \\
& Total & 3530 & 100.0 \\
\hline
\end{tabular}




\begin{tabular}{llcc}
\hline & Physical education & 94 & 2.6 \\
& CEIT* & 306 & 8.6 \\
& Science & 562 & 15.8 \\
Departments & Fine Arts & 65 & 1.8 \\
& Mathematics & 482 & 13.6 \\
& Basic Education & 454 & 12.8 \\
& Social Science & 684 & 19.3 \\
& Turkish Language & 599 & 16.9 \\
& Foreign Languages & 307 & 8.6 \\
& Total & 3553 & 100.0 \\
\hline
\end{tabular}

* Computer Education and Instructional Technologies

When Table 1 is examined, it is seen that a rich variety of departments $(n=19)$ is included in the study. Majority of the prospective teachers were female (62\%). While the largest number of participants was from department of Social Science (19\%), the lowest number was from Fine Arts (2\%). In the study, 19 different departments were gathered into nine subject areas by taking into consideration the criteria of specific teaching fields. For instance; science, physics, chemistry and biology have been considered as "science fields", preschool and primary education departments have been considered as "basic education" and social studies, history and geography have been considered as "social fields". Turkish language education and Turkish Language and Literature departments have been considered as Turkish language. Department of foreign languages consists of English, German and French languages.

\section{Data Collection}

The survey form used for data collection was composed of three sections. The first section covers personal information, the second section covers eight questions prepared by Tondeur et al. (2012), involving variables about integrating technology in education, and the third section covers 27 items covered by the TPACK-ISTE self-efficacy scale developed by Simsek and Yazar (2016). An example of the items related to the variables in training prospective teachers to integrate technology in education, is: "How do you rate the way in which the teaching staff (lecturer, instructors, professors etc.) guide you in the use of technology in education during your university course?"

The items in the TPACK-ISTE self-efficacy scale are based on performance indicators representing both TPACK and ISTE standards developed in 2008 for teachers (ISTE, 2014). In the scale, items such as "I can design learning environments to develop students' learning skills based on their co-operation" and "I can arrange learning environments to develop students' creative thinking skills" comply with ISTE's principles such as facilitating students' learning, encouraging creativity and its other dimensions. The scale used for data collection in the present study is composed of six dimensions, which are: TK (Technological Knowledge), PK (Pedagogical Knowledge), CK (Content Knowledge), PCK (Pedagogical Content Knowledge), TPK (Technological Pedagogical Knowledge) and TPACK (Technological Pedagogical Content Knowledge). 


\section{Data Analysis}

In this study, the TPACK-ISTE self-efficacy scores of prospective teachers and variables scores about training them for technology integration in education were not normally distributed. Accordingly, analyses were conducted using the Mann-Whitney $\mathrm{U}$ and Kruskall-Wallis $\mathrm{H}$ tests for the comparisons.

The significance of differences between mean scores was statistically tested at (.05/9=.0055) .0055 level with Bonferroni correction (Field, 2009) due to the possibility of significant difference emerging by coincidence and with the aim of not making a Type I error. Also significant difference was determined by taking the effect size of significant difference in consideration (Cohen, 1988). In the third sub-problem, the Spearman Brown test was used to determine whether the numbers of significant differences in TPACK-ISTE self-efficacy and variables scores about training them for technology integration in education are correlated in point of subject areas.

Kruskal Wallis test is utilized to determine significant differences, and Mann Whitney $U$ test is used as a post hoc test to determine which groups differ (Field, 2009). However, the results of the comparisons made in this way cannot reveal detailed tablature, how often the subject area scores are significantly higher or lower according to the other subject areas. For example, for each variable (e.g. technology knowledge) in the TPAB, 36 comparisons are required with the calculation in the $\left(\begin{array}{l}n \\ 2\end{array}=\frac{n \cdot(n-1)}{2}\right)$ formula for the subject areas $(n=9)$. In this study, a total of $36 \times 7=252$ comparisons were made for 7 variables in determining the significant differences between TPAB-ISTE scores. Similarly, 36x8=288 comparisons were made in variables of training prospective teachers to integrate technology in education. For a study involving such an intensive comparison table, an examination of groups that differ only significantly (both $p<.0055$ and at least $r>.10$ effect size) could better serve sub-problems of this study. As a result, a new table was created to show significant difference counts of the subject areas in favor and not in favor of according to the scores. The number of significant differences in favor of subject area is indicated as "Favorable" and the number of significant difference not in favor of (against) subject area is indicated as "Unfavorable".

The mean scores in the 5-point Likert scale have been divided into various levels. Accordingly, a calculation ((the number of options - 1) / options (0.80)), in which the self-efficacy level corresponds with each range, was made. Levels have been converted into the following options: .00-1.80: "I completely disagree"; 1.81-2.60: "I disagree"; 2.61-3.40: "I somewhat agree"; 3.41-4.20: "I agree", and 4.20-5.00: "I completely agree" to determine the TPACK-ISTE self-efficacy of prospective teachers. The Cronbach Alpha internal consistency coefficient of the TPACK-ISTE self-efficacy scale was .94 for the general scale.

\section{Findings}

\section{Examining TPACK-ISTE Self-Efficacy of Prospective Teachers}

The results of the Kruskal-Wallis $\mathrm{H}$ test conducted to determine difference between mean scores are presented in Table 3. 
Table 3. Kruskall Wallis - $\mathrm{H}$ test Results of TPACK-ISTE Self -Efficacy Scores by Subject Areas

\begin{tabular}{lccccccc}
\hline & TK & PK & CK & PCK & TPK & TPACK & TPACK-ISTE \\
\hline $\mathrm{n}$ & 3553 & 3553 & 3553 & 3553 & 3553 & 3553 & 3553 \\
$\chi^{2}$ & 105.74 & 68.33 & 85.49 & 38.77 & 108.13 & 76.59 & 70.77 \\
$\mathrm{df}$ & 8 & 8 & 8 & 8 & 8 & 8 & 8 \\
$\mathrm{p}$ & .001 & .001 & .001 & .001 & .001 & .001 & .001 \\
\hline
\end{tabular}

Table 3 indicates that there are statistically significant differences in all sub-dimensions of the TPACK-ISTE self-efficacy in Kruskal-Wallis $\mathrm{H}$ test $(p<.05)$. The Mann-Whitney $\mathrm{U}$ test was used to determine between which subject areas these differences emerged. The distribution of these differences in the sub-dimensions of the scale and the total numbers are presented in Table 4.

Table 4. Number of Favorable and Unfavorable Significant Differences in TPACK-ISTE SelfEfficacy Scores by Subject Areas

\begin{tabular}{|c|c|c|c|c|c|c|c|c|c|c|c|c|c|c|c|c|}
\hline & \multicolumn{8}{|c|}{ Number of favorable differences } & \multicolumn{8}{|c|}{ Number of unfavorable differences } \\
\hline & $\stackrel{\vee}{F}$ & $\stackrel{v}{a}$ & 壬 & 迄 & 产 & 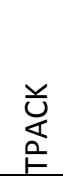 & 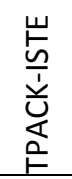 & $\begin{array}{l}\bar{\pi} \\
\stackrel{\Gamma}{0} \\
\end{array}$ & $\stackrel{F}{F}$ & 商 & 兑 & Uั & 产 & 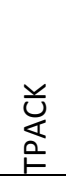 & 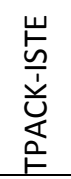 & $\begin{array}{l}\bar{\pi} \\
\stackrel{0}{\circ}\end{array}$ \\
\hline Physical Education & 0 & 0 & 6 & 0 & 3 & 2 & 2 & 13 & 1 & 0 & 0 & 0 & 0 & 0 & 0 & 1 \\
\hline CEIT & 6 & 1 & 0 & 0 & 5 & 2 & 3 & 17 & 0 & 0 & 2 & 1 & 0 & 0 & 0 & 3 \\
\hline Science & 0 & 2 & 0 & 2 & 2 & 2 & 2 & 10 & 1 & 1 & 4 & 0 & 2 & 0 & 1 & 9 \\
\hline Fine Arts & 0 & 0 & 0 & 0 & 0 & 0 & 0 & 0 & 0 & 0 & 0 & 0 & 0 & 0 & 0 & 0 \\
\hline Mathematics & 0 & 0 & 3 & 0 & 0 & 0 & 0 & 3 & 1 & 4 & 1 & 3 & 5 & 6 & 5 & 25 \\
\hline Basic Education & 0 & 3 & 0 & 1 & 2 & 2 & 2 & 10 & 1 & 0 & 3 & 0 & 2 & 0 & 0 & 6 \\
\hline Social Science & 0 & 0 & 0 & 0 & 0 & 1 & 0 & 1 & 1 & 2 & 3 & 1 & 3 & 1 & 2 & 13 \\
\hline Turkish Language & 0 & 0 & 1 & 0 & 0 & 0 & 0 & 1 & 1 & 3 & 1 & 2 & 5 & 5 & 5 & 22 \\
\hline Foreign Languages & 0 & 4 & 4 & 4 & 5 & 3 & 4 & 24 & 0 & 0 & 0 & 0 & 0 & 0 & 0 & 0 \\
\hline General Scores & 6 & 10 & 14 & 7 & 17 & 12 & 13 & 79 & 6 & 10 & 14 & 7 & 17 & 12 & 13 & 79 \\
\hline
\end{tabular}

* CEIT: Computer Education and Instructional Technologies

According to Table 4 in which all sub-dimensions and TPACK-ISTE self-efficacy scores differences are shown in a comparative way, it is seen that 79 significant differences emerged. While prospective teachers in the CEIT field have generally higher scores in the TK and TPK dimensions, those in Physical Education have higher scores in the CK dimension. Those in Foreign Language department have similarly high scores except for TK. In contrast, unfavorable differences for Mathematics, Turkish language participants are seen especially in TPK, TPACK and TPACK-ISTE except for the TK and CK dimensions. These differences show that the subject area affects the self-efficacy beliefs of prospective teachers regarding technology integration in education. 


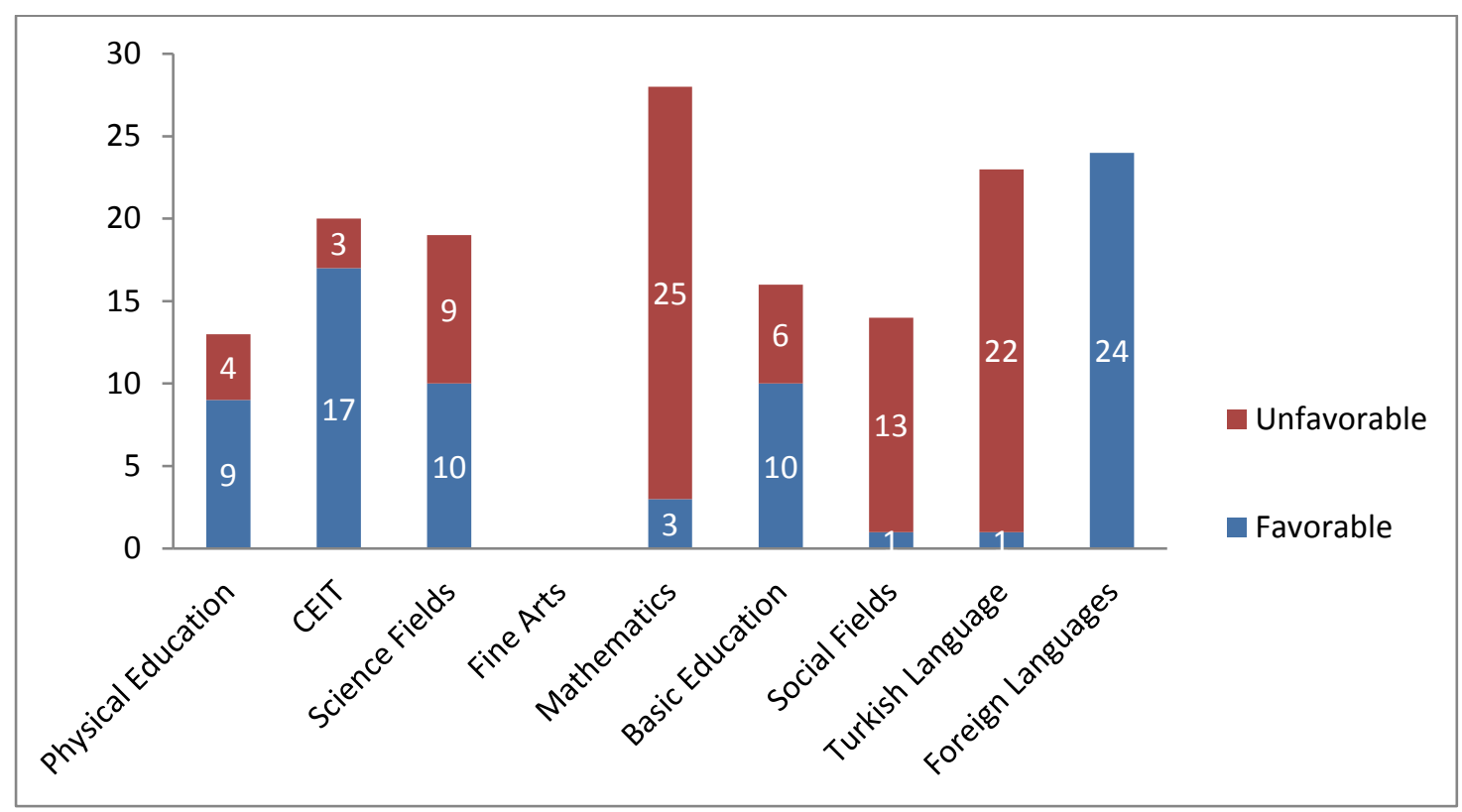

Figure 2 . The Total Number of Favorable and Unfavorable Differences in Scores for TPACK-ISTE Self- Efficacy by Subject Area

As seen in Figure 2, in comparisons made by subject area in the Mann Whitney $U$ test, the numbers of favorable significant differences are, respectively, Foreign Languages $(n=24)$, CEIT $(n=17)$, Physical education ( $n=13)$, Basic Education $(n=10)$ and Science Fields $(n=10)$. When the situations, in which differences are unfavorable are examined, it is seen that the highest are Mathematics $(n=25)$, Turkish language $(n=22)$ and Social Fields $(n=13)$.

\section{Examining Variables in Training Prospective Teachers to Integrate Technology in Education}

The number of participants answering the questions about the distributions of variables in training prospective teachers to integrate technology in education, the mean scores regarding the answers, standard deviation values and results regarding the levels are presented in the Table 5.

Table 5. Distribution of Variables in Training Prospective Teachers to Integrate Technology in Education

\begin{tabular}{lcccc}
\hline Variables & $\mathrm{n}$ & $\overline{\mathrm{X}}$ & $\mathrm{Sd}$ & Levels \\
\hline Capacity of using computers & 3529 & 3.55 & 0.83 & Agree \\
Capacity of using the internet & 3515 & 3.85 & 0.80 & Agree \\
Attitude towards using technology in education & 3523 & 3.82 & 0.85 & Agree \\
Access to technology resources & 3527 & 2.80 & 1.01 & Somewhat Agree \\
Teacher educators as role models & 3527 & 2.72 & 1.01 & Somewhat Agree \\
Authentic technology integration experiences & 3514 & 3.05 & 0.94 & Somewhat Agree \\
Using ICT when developing educational materials & 3530 & 3.06 & 0.95 & Somewhat Agree \\
Collaborating with peers & 3531 & 3.01 & 0.98 & Somewhat Agree \\
\hline
\end{tabular}

When Table 5 is examined, the variables of "teacher educators as role models" and "access to technology resources" are the two which have the lowest means, at the level of "I somewhat agree" in regard to training prospective teachers to integrate technology in education. In 
addition, the capacity to use the internet and attitudes towards using the technology in education are the highest variables, at the level of "I agree". The other variables have been evaluated at the level of "I somewhat agree".

Table 6. Kruskall Wallis - $\mathrm{H}$ test Results of the Variables about Training Prospective Teachers to Integrate Technology in Education by Subject Areas

\begin{tabular}{lcccc}
\hline Variables & $\mathrm{n}$ & $\chi^{2}$ & $\mathrm{df}$ & $\mathrm{p}$ \\
\hline Capacity of using computers & 3529 & 227.978 & 8 & .001 \\
Capacity of using the internet & 3515 & 165.882 & 8 & .001 \\
Attitude towards using technology in education & 3527 & 132.571 & 8 & .001 \\
Access to technology resources & 3527 & 98.255 & 8 & .001 \\
Teacher educators as role models & 3523 & 81.876 & 8 & .001 \\
Authentic technology experiences & 3514 & 151.310 & 8 & .001 \\
Using ICT when developing educational materials & 3530 & 180.009 & 8 & .001 \\
Collaborating with peers & 3531 & 190.044 & 8 & .001 \\
\hline
\end{tabular}

As seen in the Table 6, there are statistically significant differences between all variables with regard to training prospective teachers to integrate technology in education according to subject areas $(p<.05)$. The Mann-Whitney $U$ test has been used to determine between which subject areas these differences emerged. The differences in variables in regard to training prospective teachers to integrate technology in education in terms of these subject areas have been accordingly transformed into numeric expressions of favorable and unfavorable significant differences. The distribution and total numbers of these differences in the subdimensions are presented in the Table 7.

Table 7. Comparing the Numbers of Favorable and Unfavorable Significant Differences in the Variables about Training Prospective Teachers to Integrate Technology in Education Scores by Subject Areas

\begin{tabular}{|c|c|c|c|c|c|c|c|c|c|c|c|c|c|c|c|c|c|c|}
\hline & \multicolumn{9}{|c|}{ Number of favorable differences } & \multicolumn{9}{|c|}{ Number of unfavorable differences } \\
\hline & 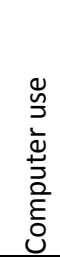 & 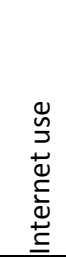 & 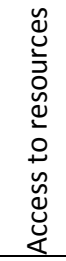 & $\begin{array}{l}\frac{\omega}{0} \\
\frac{0}{0} \\
\frac{1}{E} \\
\frac{0}{0} \\
\frac{0}{\omega}\end{array}$ & 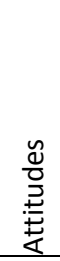 & 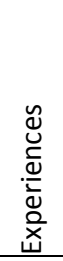 & $\begin{array}{l}\frac{0}{0} \\
\frac{0}{0} \\
\frac{d}{0} \\
\frac{\pi}{0} \\
\frac{\pi}{2} \\
\frac{\pi}{\pi}\end{array}$ & 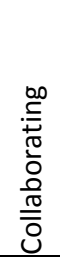 & $\begin{array}{l}\overline{\widetilde{\pi}} \\
\text { 0 } \\
\end{array}$ & 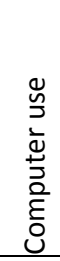 & 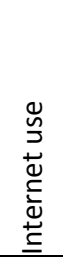 & 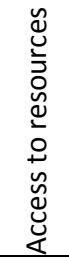 & $\begin{array}{l}\frac{\omega}{d} \\
\frac{0}{0} \\
\frac{E}{E} \\
\frac{0}{0} \\
\frac{0}{\omega}\end{array}$ & 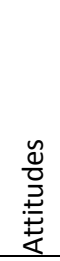 & 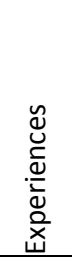 & $\begin{array}{l}\frac{0}{0} \\
\frac{0}{0} \\
\frac{0}{0} \\
\frac{\pi}{2} \\
\frac{\pi}{2} \\
\frac{\pi}{\pi} \\
\sum\end{array}$ & 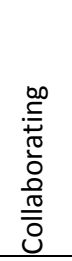 & $\begin{array}{l}\bar{\pi} \\
\stackrel{\widetilde{0}}{0} \\
\end{array}$ \\
\hline Physical Education & 0 & 0 & 0 & 0 & 0 & 0 & 1 & 3 & 4 & 2 & 2 & 1 & 1 & 0 & 1 & 1 & 1 & 9 \\
\hline CEIT & 7 & 7 & 8 & 8 & 6 & 8 & 6 & 8 & 58 & 0 & 0 & 0 & 0 & 0 & 0 & 0 & 0 & 0 \\
\hline Science & 1 & 0 & 0 & 4 & 0 & 1 & 1 & 1 & 8 & 2 & 2 & 2 & 1 & 3 & 1 & 3 & 3 & 17 \\
\hline Fine Arts & 2 & 0 & 0 & 0 & 0 & 0 & 0 & 0 & 2 & 0 & 1 & 2 & 4 & 2 & 1 & 3 & 4 & 17 \\
\hline Mathematics & 0 & 0 & 0 & 0 & 0 & 0 & 0 & 0 & 0 & 3 & 2 & 1 & 3 & 3 & 4 & 5 & 5 & 26 \\
\hline Basic Education & 0 & 0 & 1 & 2 & 1 & 1 & 3 & 3 & 11 & 1 & 1 & 1 & 1 & 1 & 1 & 0 & 1 & 7 \\
\hline Social Science & 0 & 0 & 0 & 0 & 0 & 0 & 0 & 0 & 0 & 2 & 2 & 1 & 2 & 2 & 2 & 2 & 2 & 15 \\
\hline Turkish Language & 0 & 0 & 0 & 0 & 0 & 0 & 0 & 0 & 0 & 4 & 2 & 1 & 2 & 2 & 2 & 2 & 3 & 18 \\
\hline Foreign Languages & 5 & 5 & 0 & 1 & 5 & 3 & 5 & 5 & 29 & 1 & 0 & 1 & 1 & 0 & 1 & 0 & 1 & 5 \\
\hline General Scores & 15 & 12 & 10 & 15 & 13 & 13 & 16 & 20 & 114 & 15 & 12 & 10 & 15 & 13 & 13 & 16 & 20 & 114 \\
\hline
\end{tabular}

In Table 7, it is seen that prospective teachers in CEIT received high scores in all the variables. Participants in the Foreign Language subject area also received higher scores in using computers and using the internet, using ICT in developing materials about their subject area 
and conducting collaborative activities in using technology, having authentic experiences in using technology in education, having positive attitudes towards technology integration than those in other subject areas.

The significant differences in the variables of conducting collaborative activities $(n=5)$, developing materials about the subject area $(n=5)$ and having authentic experiences of using technology in education $(n=5)$ of Mathematics prospective teachers were notably lower than those of other groups. Similarly, prospective teachers in Turkish language field has significantly lower scores than in other subject areas in using the internet $(n=4)$ and conducting collaborative activities ( $n=3)$.

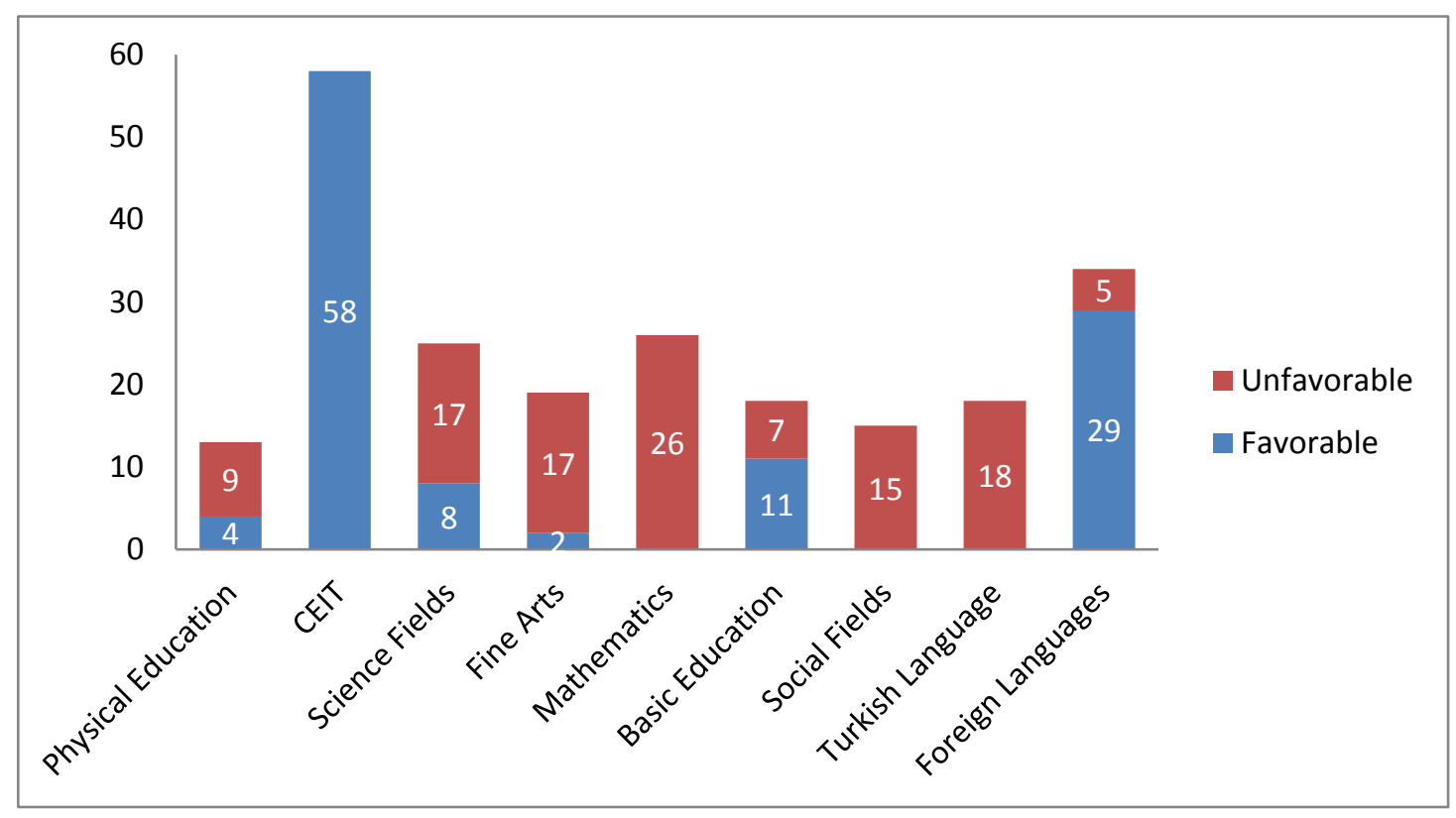

Figure 3. The Total Number of Favorable and Unfavorable Differences by Subject Area in Scores for Variables in Training Prospective Teachers to Integrate Technology in Education

Figure 3 shows that CEIT prospective teachers frequently $(n=58)$ have statistically higher scores in answers about variables than those in other subject areas. Furthermore, those in the Foreign Language field received higher scores $(n=29)$ than those in other subject areas. Those in the Basic Education area $(n=11)$ followed.

When the groups, in which unfavorable significant differences were found are examined in Figure 2, Mathematics $(n=26)$ and Turkish language $(n=18)$ are the areas which frequently showed unfavorable differences. The Science Fields $(n=17)$, Fine Arts $(n=17)$ and Social Fields $(n=15)$ followed these groups.

\section{Relationship between Numbers of Differentiation in TPACK-ISTE Self-Efficacy Scores According to Subject Area and Numbers of Differentiation in Variable Scores in Training Prospective Teachers to Integrate Technology in Education}

The relationship between numbers of differentiation in TPACK-ISTE self-efficacy scores according to subject area and numbers of differentiation in variable scores in regard to training 
prospective teachers to integrate technology in education was examined with the Spearman Brown test. A strong, significant relationship was found between situations in favor of differentiation numbers in TPACK-ISTE self-efficacy scores according to subject areas and situations in favor of variables scores in terms of training prospective teachers to integrate technology in education $(r=.81 ; p<.01)$.

A strong, significant relationship was found between unfavorable situations for significant difference numbers in TPACK-ISTE self-efficacy scores according to subject area and unfavorable situations for scores for variables in training prospective teachers to integrate technology in education $(r=.74 ; p<.02)$.

\section{Discussion and Conclusion}

In this study, a large prospective teachers sample from several subject areas is examined in point of TPACK self-efficacy and some variables affecting their training to integrate technology in education. The variables stated here reveal the capacity perceptions of prospective teachers as well as technology integration status of teacher training institutions in Turkey. Although these institutions are responsible for preparing prospective teachers to the extent of TPACK competencies, they are less focused in the educational technology studies or they have primarily focused on ICT knowledge and skills in the introductory ICT courses (Tondeur, Aesaert, Pynoo, van Braak, Fraeyman, \& Erstad, 2017). Also, investigating TPACK self-efficacy and preparing prospective teachers to integrate technology in education in terms of prospective teachers' subject area may contribute to realize the nature of a subject area to structure the curriculum and make up shortages for educational technology.

In this study, TPACK self-efficacy of prospective teachers in different subject areas differed significantly. In addition, prospective teachers had significantly different views on the process of training for technology integration in education. In particular, some branches differed predominantly in this regard, while others reported less positive opinions on the same issue. Especially scores of TPACK-ISTE self-efficacy of prospective teachers in Foreign Language are considerably high in the study. On the other hand, the fact that TPACK-ISTE self-efficacy scores of Mathematics and Turkish language prospective teachers are lower than the other subject areas in the study are striking. This study has shown that those having higher scores feel better at using computers and the internet, developing materials about their subject area and conducting collaborative activities in using technology than other groups.

Accordingly, some subject areas are exposed to technology integration in education at different levels in terms of the nature of the discipline, the qualifications of the teachers or the curricula, while being educated as a teacher. In fact, it is thought that prospective teachers' integration of technology in education process is mostly related to the teaching staff who train them. In this context, instructors should develop course activities with current pedagogical approaches and technologies in teacher training institutions. As a result of the study teacher educators are not seen as role models in using technology in education. If educators in teacher training institutions have little or lack the knowledge and experience about technology integration in education (Tondeur et al., 2012), it does not make sense to expect prospective teachers to use technology effectively in their future teaching processes (Baylor \& Ritchie, 2002; Voogt \& McKenney, 2017). The fact that prospective teachers observe their own 
teachers using technology in education is a factor which encourages them to use technology in the future.

The results of the present study show that TPACK is perceived differently in each discipline and that technological opportunities in institutions training teachers, the qualifications of teaching staff and curriculum in education differ in terms of technological integration. Those in Mathematics and Turkish language fields received low scores in terms of variables affecting training prospective teachers in integrating technology with TPACK-ISTE self-efficacy. Mathematics and Turkish subject areas have the highest weekly course hours from primary school to university level in Turkey; that is why, effective curriculum and teacher training are crucial for every aspect of education including technology integration for these groups. In terms of language teaching, although generally Turkish or a foreign language has similar disciplinary understanding, the results about technology integration and TPACK self-efficacy significantly differed. In a sense, training Turkish language prospective teachers may still be trained based on conventional manner. Studies in the literature conducted about TPACK or technology integration have concluded that the TPACK perceptions of mathematics teachers or mathematics prospective teachers are at the moderate or lower level (Ozgen, Narli, \& Alkan, 2013; Kula, 2015). According to some studies conducted in Turkey, Turkish Language and Literature and Turkish prospective teachers think that the use of Information Technologies (IT) has a negative impact on Turkish (Gezgin \& Silahsizoglu, 2016), corrupts the structure of Turkish and causes degeneration of the language (Yaman \& Erdogan, 2007). Dargut and Celik (2014) stressed in another study that although Turkish prospective teachers have positive attitudes and thoughts about using technology in education, teacher educators mostly do not have enough information about technology and support for technology in particularly public schools is inadequate.

According to the results, prospective teachers think that the possibilities in accessing to technology resources, teacher educators as role models in using technology in education, authentic technology integration experiences and using ICT when developing educational materials have lacks in their undergraduate education processes. Hereunder, it can be said that prospective teachers' positive beliefs about their TPACK self-efficacy can play an important role in organizing and carrying out the teaching profession in the future (Bandura, 1995); however, they also think the curriculum did not include experience-based technology integration activities and their teachers were not well qualified in integrating technology in education. They are in need of experiences and environment about how to integrate pedagogy and technology knowledge (Hirca \& Simsek, 2013).

Another important result of the study is that there was a significant positive relationship between training for technological integration according to subject areas and TPACK-ISTE selfefficacy. Therefore, experiences of integrating technology and access to technology in teacher training institutions, and teacher educators as role models in using technology in education are all related to the TPACK-ISTE self-efficacy of prospective teachers (Tondeur, Scherer, Siddiq, \& Baran, 2017) . In the context of the results of the current study, it is thought that curriculum should be structured to support prospective teachers in developing their TPACK self-efficacy through experiences, access to technological resources should be provided as required, and a "technology guidance system", supporting continuous integration of technology in institutions training teachers, should be created. 
It is thought that determining effective technology integration characteristics of instructors is an important indicator for future research. Most technology integration research is designed to investigate prospective teachers competencies; however, solving the issue in the teacher training institution level is another critical factor.

Because TPACK self-efficacy perceptions of prospective teachers in different subject areas differentiate significantly, content-based activities should be increased particularly in the Turkish Language and Mathematics subject groups in Turkey. In other words, content-based resource support and activities should be increased for disadvantaged teaching areas. In this context, it is the responsibility of the faculties of education to prepare prospective teachers to the extent of TPACK competencies. In the context of the use of technology in education, general competence areas for prospective teachers and specific competence areas specific to subject areas should be determined. This process should not be left to the random initiatives of the instructors.

As limitation of the present study, the variables taken for the training of prospective teachers are limited and are based on a single model. Accordingly, the use of measurement tools that take these variables as a dimension can produce more meaningful results.

\section{References}

Abbitt, J. T. (2011). An investigation of the relationship between self-efficacy beliefs about technology integration and technological pedagogical content knowledge (TPACK) among preservice teachers. Journal of Digital Learning in Teacher Education, 27(4), 134143. http://dx.doi.org/10.1080/21532974.2011.10784670

Albion, P. R. (2014). Pre-service teachers' TPACK confidence in a regional Australian university. Proceedings of the Society for Information Technology and Teacher Education International Conference (SITE 2014) (pp. 10-17). Association for the Advancement of Computing in Education (AACE).

Angeli, C. \& Valanides, N. (2009). Epistemological and methodological issues for the conceptualization, development, and assessment of ICT-TPCK: Advances in technological pedagogical content knowledge (TPCK). Computers \& Education, 52(1), 154-168. https://doi.org/10.1016/j.compedu.2008.07.006

Angeli, C. \& Valanides, N. (2015). Technological pedagogical content knowledge: exploring, developing, and assessing TPCK. New York: Springer.

Aydın-Gunbatar, S., Boz, Y., \& Yerdelen-Damar, S. A. (2017). Closer examination of TPACK-selfefficacy construct: Modeling elementary pre-service science teachers' TPACK-self efficacy. Elementary Education Online, 16(3), 917-934. https://doi.org/10.17051/ ilkonline.2017.330232

Bandura, A. (1986). Social foundations of thought and action. Englewood Cliffs, NJ: PrenticeHall.

Bandura, A. (1995). Exercise of personal and collective efficacy in changing societies. A. Bandura (Ed.) Self-efficacy in changing society (pp.1-45). New York: Cambridge University Press. 
Bandura, A. (1997). Self-efficacy: The exercise of control. New York: W. H. Freeman and Company.

Baran, E., Chuang, Hsueh-Hua., \& Thompson, A. (2011). TPACK: An emerging research and development tool for teacher educators. The Turkish Online Journal of Educational Technology, 10(4), 370-377.

Baylor, A. L., \& Ritchie, D. (2002). What factors facilitate teacher skill, teacher morale, and perceived student learning in technology-using classrooms? Computers and Education, 39(4), 395-414. https://doi.org/10.1016/S0360-1315(02)00075-1

Borko, H., Whitcomb, J., \& Liston, D. (2009). Wicked problems and other thoughts on issues of technology and teacher learning. Journal of Teacher Education, 60(1), 3-7. https://doi.org/10.1177/0022487108328488

Cavanagh, R. F. \& Koehler, M. J. (2013) A turn toward specifying validity criteria in the measurement of technological pedagogical content knowledge (TPACK). Journal of Research on Technology in Education, 46(2), 129-148. https://doi.org/10.1080/ 15391523.2013.10782616

Chai, C. S., Koh, J. H. L., Tsai, C. C. \& Tan, L. (2011). Modeling primary school preservice teachers' Technological Pedagogical Content Knowledge (TPACK) for meaningful learning with information and communication technology (ICT). Computers \& Education, 57, 1184-1193. https://doi.org/10.1016/j.compedu.2011.01.007

Cohen, J. (1988). Statistical power analysis for the behavioral sciences. Hillsdale, NJ: Erlbaum.

Creswell, J. W. (2012). Educational research: Planning, conducting, and evaluating quantitative and qualitative research (4th ed.). Boston, MA: Pearson.

Darby, L. (2009). Translating a "Relevance Imperative" into junior secondary mathematics and science pedagogy. Eurasia Journal of Mathematics, Science and Technology Education, 5(3), 277-288. https://doi.org/10.12973/ejmste/75279

Dargut, T. \& Celik, G. (2014). Pre-Service Turkish Language Teachers' Attitudes and Thoughts toward Use of Technology in Education. Journal of Mother Tongue Education, 2(2), 28 41. doi:10.1016/j.compedu.2011.01.007

Field, A. P. (2009). Discovering statistics using SPSS (3rd Ed.). London: Sage publications.

Gezgin, D. M. \& Silahsızoglu (2016). The impact of the use of information technologies on Turkish. Turkish Online Journal of Qualitative Inquiry, 7(1), 28-46. https://doi.org/10. 17569/tojqi.51712

Goktas, Y., Yildirim, S., \& Yildirim, Z. (2009). Main barriers and possible enablers of ICTs integration into pre-service teacher education programs. Educational Technology \& Society, 12(1), 193-204.

Harris, J.,Mishra, P., \& Koehler, M. J. (2009). Teachers' technological pedagogical content knowledge and learning activity types: Curriculum-based technology integration reframed. Journal of Research on Technology in Education, 41(4), 393-416. https://doi.org/10.1080/15391523.2009.10782536

Hirca, N. \& Simsek, H. (2013). Enhancing and evaluating prospective teachers' technopedagogical knowledge integration towards science subject. Necatibey Faculty of Education Electronic Journal of Science and Mathematics Education, 7(1), 57-82. http://dx.doi.org/10.12973/nefmed153. 
Hsu, S. (2010). Developing a scale for teacher integration of information and communication technology in grades 1-9. Journal of Computer Assisted Learning, 26(3), 175-189. https://doi.org/10.1111/j.1365-2729.2010.00348.x

ISTE (2014). ISTE Standards teachers. Retrieved on 16 December 2018 from http://www.iste. org/docs/pdfs/20-14_ISTE_Standards-T_PDF.pdf.

Jamieson-Proctor, R., Finger, G., Albion, P., Cavanagh, R., Fitzgerald, R., Bond, T., \& Grimbeek, P. (2012). Teaching Teachers for the Future (TTF) project: Development of the TTF TPACK survey instrument. Paper presented at ACEC2012: ITs Time Conference. Perth, Australia. Retrieved on 16 December 2018 from http://bit.ly/ACEC2012_Proceedings

John, P. D. \& Baggott la Velle, L. (2004). Devices and desires: subject subcultures, pedagogical identity and the challenge of information and communications technology. Technology, Pedagogy and Education, 13(3), 307-326. https://doi.org/10.1080/14759390400200188

Kabakci Yurdakul, I., Odabasi, H.F., Kilicer, K, Coklar, A.N., Birinci, G., \& Kurt, A.A. (2012). The development, validity and reliability of TPACK-deep: A technological pedagogical content knowledge scale. Computers \& Education, 58(3), 964-977. https://doi.org/10.1016/ j.compedu.2011.10.012

Karaseva, A., Siibak, A., \& Pruulmann-Vengerfeldt, P. (2015). Relationships between teachers` pedagogical beliefs, subject cultures, and mediation practices of students' use of digital technology. Cyberpsychology: Journal of Psychosocial Research on Cyberspace, 9(1). https://doi.org/10.5817/CP2015-1-6

Koehler, M. J. \& Mishra, P. (2008). Introducing TPCK. In J. A. Colbert, K. E. Boyd, K. A. Clark, S. Guan, J. B. Harris, M. A. Kelly \& A. D. Thompson (Eds.), Handbook of technological pedagogical content knowledge for educators. (pp. 1-29). New York: Routledge.

Koehler, M. J., Shin, T. S., \& Mishra, P. (2012). How do we measure TPACK? Let me count the ways. In R. N. Ronau, C. R. Rakes, \& M. L. Niess (Eds.), Educational technology, teacher knowledge, and classroom impact: A research handbook on frameworks and approaches (pp. 16-31). Hershey, PA: Information Science Reference.

Kopcha, T. J. (2010). A systems-based approach to technology integration using mentoring and communities of practice. Educational Technology Research and Development, 58(2), 175-190. DOI: 10.1007/s11423-008-9095-4

Krueger, K, Hansen, L., \& Smaldino. S. (2003). Preservice teacher technology competencies: A model for preparing teachers of tomorrow to use technology. TechTrends, 44(3), 47-50. https://doi.org/10.1007/BF02778227

Kula, A. (2015). Investigating prospective teachers' technological pedagogical content knowledge (TPACK) competences: Bartin University sample. The Journal of Academic Social Science, 3(12), 395-412.

Kula, A. \& Deryakulu, D. (2017). Different subject teachers' views, applications and suggestions about ICT integration in education. Educational Technology Theory and Practice, 7(2), 73-93. https://doi.org/10.17943/etku.267187

Lai, T., \& Lin, H. (2018). An investigation of the relationship of beliefs, values and technological pedagogical content knowledge among teachers. Technology, Pedagogy and Education, 27(4), 445-458. https://doi.org/10.1080/1475939X.2018.1496137 
Lee, M. H. \& Tsai, C. C. (2010). Exploring teachers' perceived self-efficacy and technological pedagogical content knowledge with respect to educational use of the World Wide Web. Instructional Science, 38(1), 1-21. https://doi.org/10.1007/s11251-008-9075-4

Mishra, P., \& Koehler, M. J. (2006). Technological pedagogical content knowledge: A framework for teacher knowledge. Teachers College Record, 108, 1017-1054.

Mumtaz, S. (2000). Factors affecting teachers' use of information and communications technology: a review of the literature. Journal of Information Technology for Teacher Education, 9(3), 319-342. https://doi.org/10.1080/14759390000200096

Niess, M. L. (2005). Preparing teachers to teach science and mathematics with technology: Developing a technology pedagogical content knowledge. Teaching and Teacher Education 21(2005) 509-523. https://doi.org/10.1016/j.tate.2005.03.006

Niess, M. L., Ronau, R. N., Shafer, K. G., Driskell, S. O., Harper S. R., Johnston, C., Browning, C., Ozgun-Koca, S. A., \& Kersaint, G. (2009). Mathematics teacher TPACK standards and development model. Contemporary Issues in Technology and Teacher Education, 9(1), 424. Retrieved on 2 February 2018 from https://www.learntechlib.org/p/29448/.

Ozgen, K., Narli, S., \& Alkan, H. (2013). An investigation of mathematics teacher trainees' technological pedagogical content knowledge and their perception of the frequency of technology use. Electronic Journal of Social Sciences, 12(44), 31-51.

Roblyer, M.D. (2006). Integrating educational technology into teaching (4th ed.). Upper Saddle River, NJ: Prentice Hall.

Sarac, M. (2015). An explanatory investigation on the Turkish EFL teachers' TPACK and their attitudes toward the use of interactive whiteboards (Master of Arts Thesis). Retrieved from The Council of Higher Education Theses database of Turkey. (Thesis No. 395176).

Simsek, O. \& Yazar, T. (2016, October). Validity and reliability study of technological pedagogical content knowledge self-efficacy scale based on international educational technology standards (TPACK-ISTE). Paper presented at the 1st International Conference on Lifelong Learning and Leadership for All. Olomouc, Czech Republic.

Tay, L. Y., Lim, C. P., \& Lim, S. K. (2015). Differences in ICT usage across subject areas: A case of an elementary school in Singapore. Journal of Educational Computing Research, 53(1), 75-94. https://doi.org/10.1177/0735633115585930

Tay, L. Y., Lim, S. K., \& Lim, C. P. (2013). Factors affecting the ICT integration and implementation of one-to-one computing learning environment in a primary school -A sociocultural perspective. In L. Y. Tay \& C. P. Lim (Eds.), Creating holistic technologyenhanced learning experiences: Tales from a future school in Singapore (pp. 19-37). Rotterdam, the Netherlands: Sense Publishers.

Toledo, C. (2005). A five-stage model of computer technology integration into teacher education curriculum. Contemporary Issues in Technology and Teacher Education, 5(2), 177-191.

Tondeur, J., Scherer, R., Siddiq, F., \& Baran, E. (2017). A comprehensive investigation of TPACK within pre-service teachers' ICT profiles: Mind the gap! Australasian Journal of Educational Technology, 33(3), 46-60. https://doi.org/10.14742/ajet.3504 
Tondeur, J., van Braak, J., Sang, G., Voogt, J., Fisser, P., \& Ottenbreit-Leftwich, A. (2012). Preparing pre-service teachers to integrate technology in education: A synthesis of qualitative evidence. Computers \& Education, 59, 134-144. https://doi.org/10.1016/ j.compedu.2011.10.009

Tondeur, J., van Braak, J., Siddiq, F., \& Scherer, R. (2016). Time for a new approach to prepare future teachers for educational technology use: Its meaning and measurement. Computers \& Education, 94, 134-150. https://doi.org/10.1016/j.compedu.2015.11.009

Tondeur, J., Aesaert, K., Pynoo, B., van Braak, J., Fraeyman, N., \& Erstad, O. (2017). Developing a validated instrument to measure preservice teachers' ICT competencies: Meeting the demands of the 21st century. British Journal of Educational Technology, 48(2), 462-472. https://doi.org/10.1080/1475939X.2016.1174730

Tuncer, M. (2014). The relationship between teacher efficacy and technological pedagogical content knowledge (TPACK) within the scope of EFL pre-service teachers (Unpublished master's thesis). Retrieved from The Council of Higher Education Theses database of Turkey. (Thesis No. 373608)

Voogt, J. \& McKenney, S. (2017). TPACK in teacher education: are we preparing teachers to use technology for early literacy? Technology, Pedagogy and Education, 26(1), 69-83. https://doi.org/10.1080/1475939X.2016.1174730

Voogt, J., Fisser, P., Pareja Roblin, N., Tondeur, J., \& van Braak, J. (2012). Technological pedagogical content knowledge-a review of the literature, Journal of Computer Assisted Learning, 29(2), 109-121. https://doi.org/10.1111/j.1365-2729.2012.00487.x

Waggoner, M. D. (1994). Disciplinary differences and the integration of technology into teaching. Journal of Information Technology for Teacher Education, 3(2), 175-186. https://doi.org/10.1080/0962029940030205

Wang, L., Ertmer, P. A., \& Newby, T. J. (2004). Increasing preservice teachers' self-efficacy beliefs for technology integration. Journal of Research on Technology in Education, 36(3), 231-250. https://doi.org/10.1080/15391523.2004.10782414

Wang, Q. (2008). A generic model for guiding the integration of ICT into teaching and learning. Innovations in Education and Teaching International, 45(4), 411-419. DOI:10.1080/ 14703290802377307

Yaman, H. \& Erdogan, Y. (2007). The influence of internet on the Turkish language: A Qualitative study. Journal of Language and Linguistic Studies, 3(2), 237-249.

Yeh, Y. F., Hsu, Y. S., Wu, H. K., Hwang, F. K., \& Lin, T. C. (2014). Developing and validating technological pedagogical content knowledge-practical (TPACK-practical) through the Delphi survey technique. British Journal of Educational Technology, 45(4), 707-722.

Zelkowski, J., Gleason, J., Cox, D. C., \& Bismarck, S. (2013). Developing and validating a reliable TPACK instrument for secondary mathematics preservice teachers. Journal of Research on Technology in Education, 46(2), 173-206. https://doi.org/10.1080/15391523.2013. 10782618

Zhao, Y. \& Frank, K. (2003).Factors affecting technology uses in schools: An ecological perspective. American Educational Research Journal, 40(4), 807-840. https://doi.org/ 10.3102/00028312040004807 
CONTEMPORARY EDUCATIONAL TECHNOLOGY, 2019, 10(3), 289-308

DOI: https://doi.org/10.30935/cet.590105 - TYPE: Research Article

Correspondence: Omer Simsek, Ph.D., Research Assistant, Department of Computer Education and Instructional Technologies, Ziya Gokalp Faculty of Education, Dicle University, Diyarbakir, Turkey 